Portland State University

PDXScholar

\title{
The Effects of Aging, Prolonged Life Expectancy and Retirement on the American and Japanese Social Security Systems
}

Torgen Karns

Portland State University

Follow this and additional works at: https://pdxscholar.library.pdx.edu/honorstheses

Let us know how access to this document benefits you.

\section{Recommended Citation}

Karns, Torgen, "The Effects of Aging, Prolonged Life Expectancy and Retirement on the American and Japanese Social Security Systems" (2018). University Honors Theses. Paper 560.

https://doi.org/10.15760/honors.567

This Thesis is brought to you for free and open access. It has been accepted for inclusion in University Honors Theses by an authorized administrator of PDXScholar. Please contact us if we can make this document more accessible: pdxscholar@pdx.edu. 


\title{
THE EFFECTS OF AGING, PROLONGED LIFE EXPECTANCY AND RETIREMENT ON THE AMERICAN AND JAPANESE SOCIAL SECURITY SYSTEMS
}

\author{
By Torgen Karns \\ Portland State University
}

\begin{abstract}
The Social Security Systems in the United States and Japan face issues due to demographic changes. This paper focuses on and discusses how retirement pensions are determined in each country and issues due to prolonged life expectancy and trends toward early retirement. In the United States a plan that accounts for the deficit caused by these demographic changes and then increases the payroll tax and decreases benefits accordingly would put it back onto a sustainable path. While in Japan, continuing with the initial goals of the 2004 pension reform, decreasing the replacement rate by $20 \%$ and increasing the normal retirement age would also help to alleviate Social Security's uncertain future.
\end{abstract}

\section{Introduction}

Social Security is a system that benefits many people, including the disabled, widowed and the elderly. Over the last several decades, difficulties have emerged in the Social Security systems of both Japan and the United States due to changing demographics, leaving both systems, in the current state, unsustainable. 
In the United States an increase in life expectancy around 17 years and a decrease in persons aged 65 to 69 in the labor force from $60 \%$ to $35.8 \%$ has led a rise in the amount of years that benefits have to be paid out and to a growth in the retiree to labor force ratio. This could be solved through a number of reforms, such as increasing the age at which normal and early benefits can be claimed and the introduction of individual accounts to Social Security. While every different reform can have negative effects, both seen and unforeseen, the best policy seems to be one that changes along with the system. I will, therefore, discuss many different policy reforms, and discuss both their benefits and negative effects. I will pay special attention to the Diamond and Orzag policy which is in favor of half of the deficit gap being covered by an increase in the payroll tax while the other half is covered by a decrease in benefits (Diamond and Orszag, 2004).

In Japan however, things are in a more dire situation. This is due to the fact that their life expectancy is the largest among developed nations, while their replacement rates is one of the lowest. Social Security reform has been a topic of Japan for a number of years, with latest addition to policy reform being created in 2004. One of the key elements of this policy reform was the introduction of the macroeconomic sliding scale, which decreased benefits based on a decline in the number of people insured, due to retirement, and increase in prolonged life expectancy. However, because this policy reform would likely cause the replacement rate on pensions to decrease below 50\%, its implementation was postponed (Kitao 2017).

Since Japan already has a foundation for good reform, this paper will focus on how to amend current social security policy while keeping the foundations created in 2004 in mind. Decreasing the replacement rate by $20 \%$ seems key to keeping Japan's social security system sound, along with an increase in the normal retirement age. However, when is the best time to 
implement this policy is still to be determined. While implementing it soon would cause the least amount of economic upheaval, it may not be the best option as it could negatively affect those who are retired, or in the process of retiring.

The Social Security programs, while by no means the same in either country, share similar qualities and problems. While no one policy reform could correct the system in either place, there is significant overlap in action that they could pursue. For this reason, it seems logical that a review of both countries Social Security system be discussed in this paper. The aim of this study is to (i) pinpoint possible reforms that could be sought and (ii) to uncover similarities in demographical issues they face as well as possibilities for reform that they could learn from each other.

\section{History and the Current State of the Social Security System}

In order to truly grasp the magnitude at which changing demographics will affect these two systems a basic understanding of how the system operates is required. A brief history and overview of the programs in both the US and Japan will be covered in this section.

\subsection{Social Security in the United States}

In 1934 Franklin D. Roosevelt issued and executive order to create the Committee on Economics Security and appointed the Secretary of Labor, Frances Perkins, as the first chairwoman. The committee began investigations into economic security and created proposals that were to serve as the basis for legislation and would be passed before Congress. On January $17^{\text {th }} 1935$, Roosevelt presented what the committee had found, and after consideration by congress, the Social Security Act was signed in August 1935. The first retirement check was issued to Ida May Fuller in January of 1940 (SSA, 2005). 
Since then, this program, aimed at helping the elderly, disabled and widowed, has only grown in the number of people that it provides services to. While demographics in the US have changed, and continue to change, since over two decades ago, the elderly have been expected to grow from one fifth of the population to two fifths in 2040, Social Security has changed very little (Lumsdaine and Wise, 1994). To understand what this could mean for the future of the program, it is important to understand how this program is set up in the US.

\subsubsection{Funding}

Social Security is funded in a few different ways. The main way is through a pay-as-you go-system. This means that the current working population, along with their employers, pay into the system through the form of a payroll tax. Employees and employers each pay $6.2 \%$ of the tax, for a total of $12.4 \%$ of wages that is then payed into Social Security. However, there is a cap to how much wages can be taxed, $\$ 127,200$ in 2017 (Miller, 2017). Anything above the maximum taxable earnings is not subject to the payroll tax. Benefit receivers who have an income that is higher than $\$ 25,000$, for those who file a single return, or $\$ 32,000$, for those who file a joint tax return, will also have their benefits taxed which also provides funds into the Social Security System. The final way in which funds are provided, is through the investment, namely a trust fund set up in the 1980's (Diamond and Orszag, 2004).

\subsubsection{Eligibility}

While, there are many different people who receive benefits, such as disabled workers and their family members, including spouses in families who have children and the children 
themselves, widowers and children whose parents are deceased, for the sake of this paper they will not be discussed. While these aspects of the Social Security system are extremely important and also need to be preserved, the interest of this paper is looking at how the current working population and the retired effect social security.

In order to be able to claim benefits it is required that an individual work a total of ten years within their life time (Diamond and Orszag, 2004). Presently, retirees can claim early benefits, at age 62, and full benefits, most usually referred to as normal benefits, at 66 and four

months. Currently the age at which benefits can be claimed is increasing, and will continue to do so until 2022, where normal benefits can be received at age 70 . If a retiree should choose to claim early benefits in 2018 they will receive $73.33 \%$ of their potential normal benefits, or they can receive $105.33 \%$ of their normal benefits if they delay their pension payments until age 70 (Diamond and Orszag, 2004). Those who are married also have the option to receive half of their spouse's retirement, if it is larger than the benefit that they would have received on their own (Quinn, 2013).

\subsubsection{How Benefits Are Determined}

Social Security benefits are determined through the amount of years worked, age, and earnings during years worked. Social Security is meant to serve as an aid to retirement but not as the sole source of income for retired people. Benefits are determined through four different methods: average earnings, primary insurance amount (PIA), monthly benefit amount, and indexation for inflation.

Average earnings is the measure of the average amount earned up to 60 years of age. However, not every year that a wage earner has worked is included into their benefits, only the 
35 years of the highest wage earnings are included (Diamond and Orszag, 2004). Each year of the 35 highest wage earning years is multiplied by the wage indexing factor to reflect the current average wage received, and then it is averaged and divided by 12 for each month. ${ }^{1}$ This final total is referred to as the average indexed monthly earnings (AIME). From here, the worker's PIA, is calculated.

PIA is progressive, meaning that it is a larger percentage of a claimants AIME if he/she is a low-income earner than if he/she is a high-income earner. PIA, it follows, is a sum of the first $90 \%$ of a claimants AIME through $\$ 895,32 \%$ of his/her AIME from $\$ 895$ to $\$ 5397$, and $15 \%$ of AIME that is $\$ 5397$ or higher. This calculation is represented in the equation below (based on an example for the SSA) for a claimant whose AIME is $\$ 6000$ :

$$
.9(\$ 895)+.32(\$ 5397-\$ 895)+.15(\$ 6000-\$ 5397)=\$ 2336.59
$$

EQUATION 1. How benefits are determined if AIME is $\$ 6000$

The PIA then equals the amount that benefit claimers can receive if they claim full benefits.

In the case that a wage earner delays benefits or claims early benefits the monthly benefit amount is then calculated. In the case that early benefits are claimed, the benefit amount is less than the PIA, on the other hand when benefits are delayed the benefit amount is larger than the PIA. The final part in determining monthly benefits is indexing for inflation. Each year benefits are increased to match changes in cost-of-living expenses.

\footnotetext{
${ }^{1}$ The wage indexing factor refers to the change in Aver Wage Index (AWI) computed by the Social Security Administration (SSA).
} 


\subsection{Social Security in Japan}

Japan's Social Security has a longer and more complex history by far than the US, with different forms of social security appearing through the different eras, dating all the way back to 1601. However, the modern social security system began in 1961 (Japanese Ministry of Foreign Affairs). In Japan, though, demographics are also changing rapidly, possibly in a way that is even more dangerous than in the US. It is predicted that in 2025 the ratio of elderly to workingage population will rise to .48 (Yashiro and Oshio, 1990). For Social Security within Japan to survive this demographic change, it is important that they consider reform.

\subsubsection{Funding}

The Japanese Social Security system, like the US, is a pay-as-you-go system. There are three categories within the national pension system: category I insured persons, self-employed, category II insured persons, salaried workers, and category III insured people, spouses who are dependent on their category II insured partners (Japan Pension Services, 2018). Category I insured members pay a set premium per month, ¥16,340 (\$150) in 2018 (Japan Pension Services, 2018). Category II ensured members pay an $18 \%$ payroll tax, half of which (9\%) is covered by the company that they work for. Category III members are not required to pay into the system, but receive benefits when they turn 65 (Ministry of Foreign Affairs).

\subsubsection{Eligibility}

The Japanese Social Security system, like the US system, provides benefits to many different people. It has various different programs such as social insurance, public assistance, 
health services for the elderly, etc. However, once again, for the sake of this paper I will be focusing specifically on the national pension system. All residents of Japan are enrolled under the national pension system at 20 years of age, no matter what category they register themselves under. Within category I and II insured persons, it is important that they have a total of at least 10 covered years, in order to receive benefits later. While typical coverage only extends to the age of 59, it is possible for Japanese residents to register to be covered from 60 to 64 (Japan Pension Services, 2018).

Members of the program can receive full benefits at the 65 years of age, however like in the US, members of the program have the option to claim early benefits at age 60, or they can delay benefits until age 70. For those who claim benefits at age 60 they will receive $70 \%$ of their total benefits, while those who delay benefits will receive 142\% of their benefits. (Japan Pension Services, 2018).

\subsubsection{How Benefits Are Determined}

For those who are in Category III benefits are set at $¥ 65,000$ (\$598) yen a month. Benefits for category I are based on the total amount they could receive in benefits if they worked for 40 years ( $¥ 780,000$ or $\$ 7174$ ) multiplied by the number of months they paid into the system, divided by 480 (the number of months in a 40 year period).

$$
780,000 * \frac{\text { number of contirbution paid months }}{480}
$$

EQUATION 2. How benefits for category I are determined 
Benefits for category II are determined through the number of contribution paid months, standard monthly remuneration, and the contribution rate (Japan Pension Services, 2018).

$$
\begin{aligned}
& 780,000 * \frac{\text { number of contirbution paid months }}{480}+\text { standard monthy remuneration } \\
& * \text { number of contribution paid months } *\left(\frac{5.481}{1000}\right)
\end{aligned}
$$

EQUATION 3. How benefits for category II are determined

The first part of the equation is the same as category I, total amount that could be received on benefits multiplied by the number of months contributed divided by 480 . Added to this is the amount made on average monthly income multiplied by the number of months paid into the system, and then multiplied by the benefit rate. This is the total remuneration-related portion of

\begin{tabular}{|c|c|c|}
\hline & United States & Japan \\
\hline Type of System & Pay-as-you-go & Pay-as-you-go \\
\hline Funding & $\begin{array}{l}\text { 12.4\% Payroll Tax } \\
\text { Taxation of Benefits } \\
\text { Social Security Trust Fund }\end{array}$ & $\begin{array}{l}\text { Category I: Set Premium of } ¥ 16,340 \\
\text { Category II: } 18 \% \text { Payroll Tax } \\
\text { Category III: No payment }\end{array}$ \\
\hline Who Is Eligible & $\begin{array}{l}\text { Must Work } 10 \text { Years or More } \\
\text { Early Benefits at Age } 62 \\
\text { Full Benefits at } 66 \text { and Four Months } \\
\text { Delayed Benefits Until } 70\end{array}$ & $\begin{array}{l}\text { Category I and II Must Work } 10 \text { Years or More } \\
\text { Early Benefits at } 60 \\
\text { Full Benefits at } 65 \\
\text { Delayed Benefits Until } 70\end{array}$ \\
\hline Determining Benefits & $\begin{array}{l}\text { Average Earnings } \\
\text { Primary Insurance Amount (PIA) } \\
\text { Indexation for Inflation }\end{array}$ & $\begin{array}{l}\text { Category I: See Equation I } \\
\text { Category II: See equation } 2 \\
\text { Category III: } ¥ 65,000 \text {, regardless }\end{array}$ \\
\hline
\end{tabular}
the benefits of old age.

TABLE 1: Summary of Social Security in US and Japan 


\section{Demographical Issues}

I will now outline how demographics have changed since Social Security was set up in both countries, and how that has begun to affect them negatively. Namely it will look at how demographic changes related to aging, prolonged life expectancy and retirement trends have caused these systems to become unstable. While both countries are facing similar problems, the scale and how this effects each individual system specifically is quite different.

\subsection{Demographics in the US}

Since the US was set up in 1935, the average life expectancy has grown from 61 years of age to 78.74 years of age (World Bank, World development indicators). However, Social Security has hardly changed along with it. While the age that recipients can claim full benefits increased by two years in 2018, and will continue to grow until 2022, early benefits can still be claimed at the age of 62 . Meaning that if people retire as soon as they are able to receive partial benefits, the system is paying out benefits for a total of 17 years. While this is not a problem if it is only a small part of the population, we are seeing a trend towards early retirement across the nation, and even in many countries across the globe (Japan actually exhibits less of this, which will be discussed in section 2.3).

Many people are choosing to retire early, because the US offers high benefits, even when claimed at 62 , and there is an implicit tax to continuing to remain in the labor force after the early retirement age (Gruber and Wise, 1998). In 1960, 60\% of men aged 65-69 were continuing to participate in the labor force, however in 2013 that number had fallen to $35.8 \%$ (Diamond and Gruber, 1999, Kromer and Howard, 2013). Furthermore, looking at the hazard rate out of the 
labor force for men, we see a huge spike in retirement when men reach the age of 62 , the age at which they can claim earl benefits (Diamond and Gruber, 1999).

To make matters worse in the US, the Baby Boomer generation is beginning to age and along with a decrease in birth rate nationally the median age has changed from 29 in 1960 to 37.9 in 2016 (Census, 2017). The elderly (65 years of age and older) have grown from being $12.4 \%$ of the population to $15.2 \%$ in 2016 , with baby boomers turning 65 in 2011 , the ratio of retired to labor force population is expected to continue to grow (Census, 2017).

\subsection{Issues of Changing Demographics in the US}

The effect of this change in demographics, while not necessarily an issue for the country as a whole, does pose some serious threats to the Social Security system. It is necessary that a Social Security system reflect the kind of people that are contributing and benefiting from it. This way payments into, and benefits from, the system can be fair, and most importantly, so the system can be sustainable, giving future generations the comfort in knowing that their families are secure and that they too will be able to benefit.

Aging, increasing life expectancy and trends towards early retirement increase in the retiree-to-labor-force-participant ratio which means that current workers in the labor force are having to support a higher amount of benefits that will be paid out to the retired. This process is likely going to continue in the US as the baby boomer generation continues to age. Without any change, the Social Security system could become actuarially unsound in the near future. This means that as the Social Security program's deficit increases, it begins to take up an even higher percentage of GDP as it has to pay a larger quantity of benefits to the retired (Diamond and Orzag, 2005). This can potentially jeopardize the system and its millions of contributors. 
However, while this is a possibility, there are measures that can be taken to restore balance to the system, I will considered this in section 4.

\subsection{Demographics in Japan}

Japan has the longest life span of any country in the developed world coupled with one a very low birth rate (Kitao, 2017). This means the growth rate of the labor source is less than that of the retiree population. On top of this the elderly are able to receive their full pension at the age of 65 which is one of the lowest ages in the world (Kitao, 2017). This puts a huge strain on the Social Security budget as the system has to pay pensions for an extremely long time, which accounts for the fact that it is taking up over 10\% of Japans GDP (Kitao, 2017).

Unlike the US, Japan has a very high savings rate and labor force participation rate of elders, $13.2 \%$ and 54\% respectively (Yashiro and Takashi, 1999). While the labor force participation of the elderly is relatively high, it has decreased from 70\% in 1960 (Yashiro and Takashi, 1999). The high participation rate can be attributed to the fact that retirement is not a requirement for receiving pensions, as members who are enrolled in the pension plans begin receiving benefits as soon as they turn 65 . It can also be contributed to the high labor demand, caused by the decrease in the size of the labor force participation group that has been declining since 1995 .

The population aged 65 and over has increased from $9.1 \%$ in 1980 to $23 \%$ in 2010 (Tokyo: The Japan Institute for labour policy and training, 2014). This process is one that is only going to continue to grow as the elderly population is expected to continue to increase until 2050 , reaching $80 \%$ of the population. This is due both to the large increase in life expectancy, but also to Japan's extremely low fertility rate (Kitao, 2017). With this continued increase in an 
elderly population, the amount of pensions that will have to be dispensed will only continue to grow.

\subsection{Issues of Changing Demographics in Japan}

Demographical change in Japan poses an extremely interesting and difficult situation for Japan as a whole. However, most notably, the future of Social Security within Japan, specifically the pension plan, is extremely dire. With the rapidly increasing elderly population, as can be seen in Figure 2 below, pension expenditures will soar to an unmanageable point (Kitao, 2017).

Because the fertility rate (Figure 1) is extremely low and life expectancy is very high the population in Japan will rapidly decline, a process which has already begun. This means that fewer and fewer people will be paying into the pension fund as more elderly people exit the labor market and fewer young people begin to fill their spots.

While the elderly are not retiring early, like in many parts of the world, they too will eventually have to retire. By 2060 the elderly population is estimate to account for $40 \%$ of the population, while in that same year, citizens under 19 will only account for 13\% (Marlow, 2015). This means that soon the cost of Social Security will grow even larger, but its source of funding, the payroll tax, will continue to shrink.

Another dilemma facing the system is the Category III members. While Category I, selfemployed persons, and Category II, those employed by corporations, both contribute to funding pensions, Category III, spouses of Category II persons, receive payments from the system, without joining the labor force and thus also without contributing either through premiums or the payroll tax. As will be seen in later sections, this paper will not advocate for the elimination of 
Category III, however its effect on the system is one that cannot go unnoted, and its removal from the program is a topic that continues to be a source for debate.

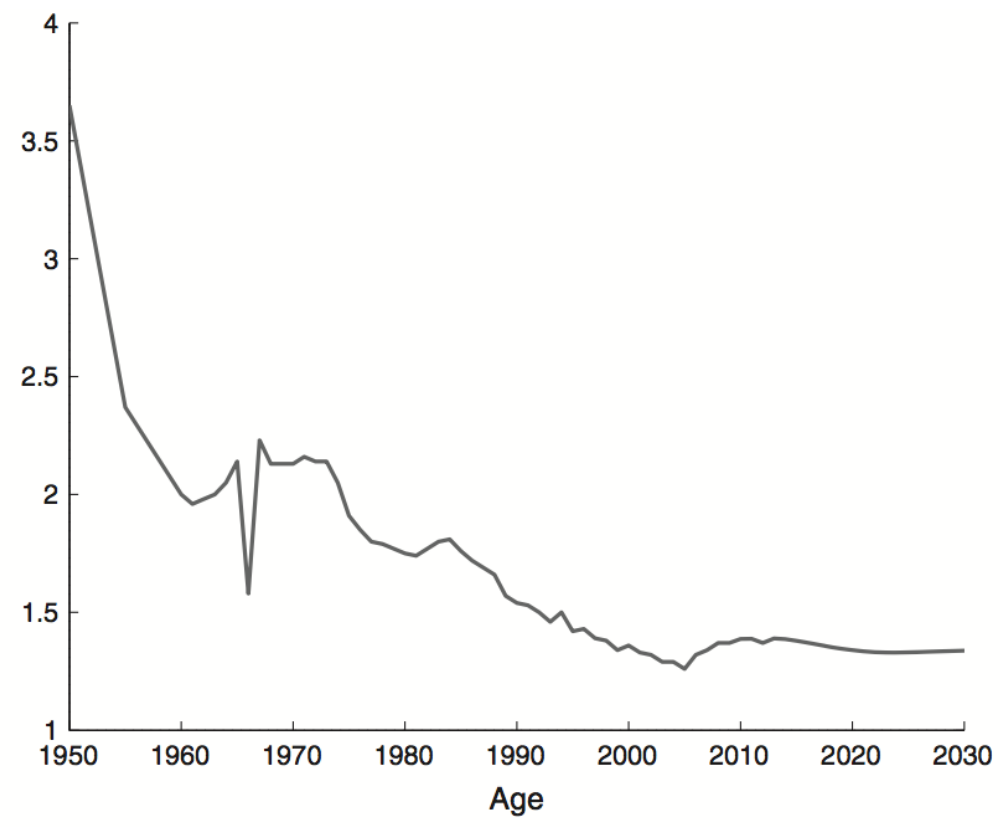

FIGURE 1. Total Fertility Rate

Source: Kitao (2017).

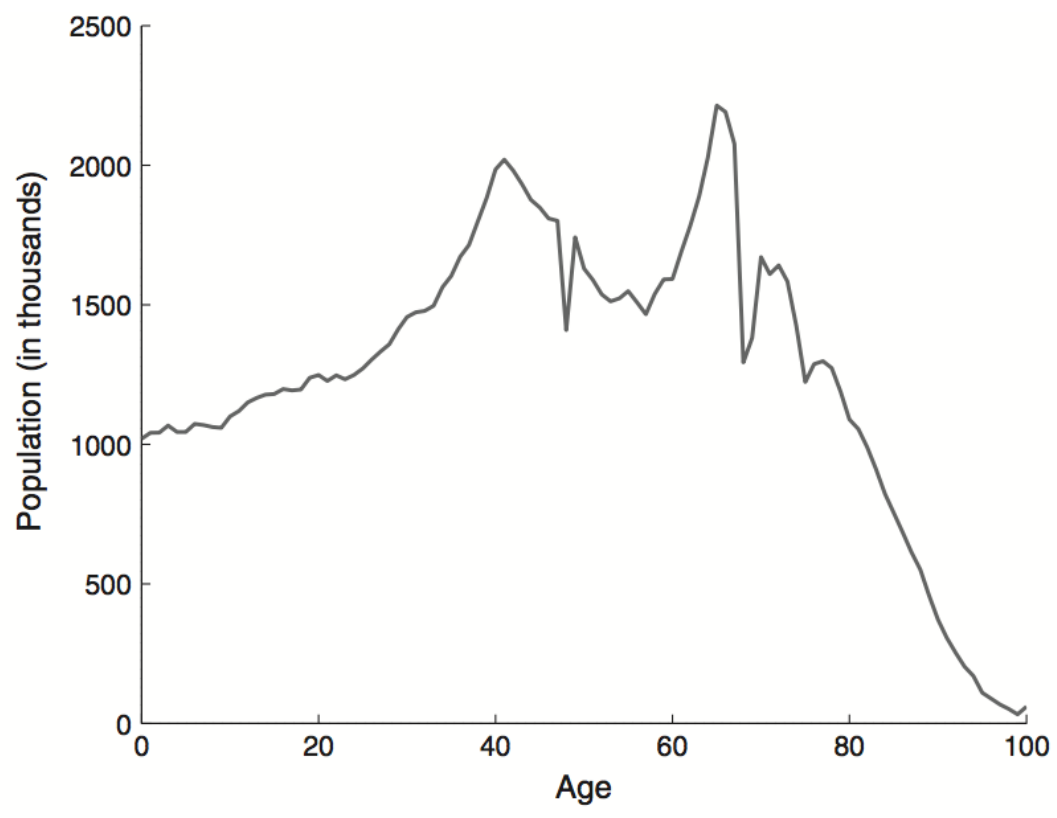

FIGURE 2. Population by age in 2014

Source: Kitao (2017) 
Japan is currently in a precarious situation as the system will be required to pay more and more in pension funds while at the same time receiving fewer and fewer contributions. While Japan has increased its contribution rate from $13.58 \%$ in 2014 to $18.3 \%$ in 2017, preliminary analyses suggest that this change may not be enough to make the pension system sustainable (Kitao, 2017). More reform is needed in order to create a well-functioning program, which will be discussed in the next section.

\section{Possible Policy Reforms}

There are several reform possibilities that could help to minimize negative effects that have emerged due to changing demographics in both the US and in Japan. While it can be very difficult to know what negative externalities may arise from a change in policy, it is still imperative that some form of change does take place, as it is very clear that neither system can continue in its current state.

This section discusses four different possible policy reforms that could help Social Security in the US. Special attention is paid to the plan outlined by Peter Diamond (2010 Nobel Peace Prize winner in economic sciences) and Peter Orzag (Vice Chairman of Investment Banking at Lazard). On the other hand, I will only focus on one main reform for Japan proposed by Sagiri Kitao, winner of the 2016 Nakahara Prize, that works in accordance with the 2004 policy reform.

\subsection{Policy Reforms in the US}


While it is clear that there needs to be a change to the Social Security system, it can be unclear which policy can be best to pursue, or which issue should be tackled first. From here I will outline four different possibilities for Social Security Reform.

\subsubsection{Individual Accounts}

The first policy that could be pursued would be switching from current Social Security, to a hybrid where benefits are reduced and an individual accounts are substituted in (Diamond and Gruber, 1999). This would involve a system where receivers of future Social Security benefits do not pay into the system initially, and instead pay into their individual account (such as a $401 \mathrm{~K})$. Then when they become eligible for social security their benefits are reduced by the amount they would have been paying into the system had they been paying a payroll tax. Through this reduction in benefits no deficit occurs, as they are receiving smaller pensions. (Diamond and Orzag, 2005).

However, several issues arise from a system like this. The first being the initial deficit that Social Security trust fund would incur. If this system was implemented today, it would be about 40 years before the first set of reduced benefits would be handed out (as the new generation of Social Security eligible recipients reached the age that they could start claiming benefits) and it would be several more years before this deficit could be covered (Diamond and Orzag, 2005). Furthermore, the Social Security trust fund will always be lower, as there will be constant outstanding loans. The only way to solve this problem would be to reduce benefits further or increase the payroll tax, a method of creating an actuarially sound Social Security system that we will address later on in this section (Diamond and Orzag, 2005). 
Furthermore, individual accounts are not, as of yet, indexed for inflation (Diamond and Orzag, 2005). While this is something that could be changed, and perhaps should be regardless, it would create an added difficulty of trying to amend social security. There is also the issue of access to funds before retirement, as there is in a $401 \mathrm{~K}$. If individual accounts where to be introduced to Social Security, it is likely that there would be political pressure to create preretirement access. This would erode the point of Social Security which is to make sure that people have access to funds, untouched, after retirement (Diamond and Orzag, 2005).

\subsubsection{Increase in required age}

Another possible solution is to raise either the early or normal benefits age (Diamond and Gruber, 1999). Doing this would decrease the incentive for workers to retire early because retiring before one has the ability to receive their monthly pension would cause a significant drain on personal savings. This would also decrease how many years Social Security is required to hand out benefits, an issue that has emerged due to increasing life expectancy.

However, further increases in the age that participants can claim benefits seems undesirable because an individual's need to retire is not based solely on life expectancy, and it is therefore unfair to expect individuals to work longer, when it may be very physically or mentally taxing (Diamond and Orzag, 2004). Furthermore, as life expectancy continues to increase, as well as the gap between high and low earners, so will the gap in age of death for those with high earnings versus those with low earnings. For this reason, especially, it is necessary to have the option to retire early, so that those with shorter life expectancies can choose to retire early and enjoy end of life benefits (Diamond and Orzag, 2004). 


\subsubsection{Prefunding}

The US could also try and fund future consumption through Social Security by investing in future claims to other countries future output (Noguchi and Wise, 1994). This would mean investing in stocks from other countries, which will then hand out dividends which can then be placed in the Social Security trust fund. Then as the retiree ratio begins to increase, as well as the amount of years that social security is being paid out, there will be more money to fall back on, and help the system to remain actuarially sound.

However, there are a few issues with this plan. The first issue arises from having a trade deficit, which has led to countries owning claims in the United States, and not the other way around (Noguchi and Wise, 1994). Another issue is that this is only a short-term solution to the problem at hand. While this may be able to fill the gap created by the baby boomer generation retiring, it will not solve the problem forever, as it is possible that the trend towards early retirement may worsen, or, more likely, life expectancy will continue to increase. This solution does not allow for demographics to continue changing forever, as it will. It only provides a shortterm fix, until the next problem arises.

\subsubsection{The Diamond and Orzag Plan}

A compelling argument, put forth by Peter Diamond and Peter Orzag, is one that proposes changes that are congruent with its demographics. This could be implemented through an increase in the payroll tax and a decrease in benefits for people who are 59 or younger (retirees who are 60 or above will not be affected). To accomplish this the Office of the Chief Actuary will do a yearly check of expected increases in life expectancy, and will conduct research to determine what the net cost is to Social Security. Once determined, half of this will 
be covered by reductions in PIA, while the other half will be covered by an increase in payroll tax. This method would reduce the actuarial deficit (Diamond and Orzag, 2004).

This could be a very difficult policy reform, as it is not one that politicians are likely to support. Both decreasing benefits and increasing taxes are policies that are likely to make politicians unpopular.

\subsection{Policy Reform in Japan}

Japan has an even larger fiscal challenge ahead of them due to the quickly rising increase in retirees stemming from the low fertility rate and the tremendous increase in life expectancy. In 2004 Japan introduced a new pension reform that was passed. It had three main points that it focused on: 1) increasing the contribution rate, the amount contributed to Social Security through the payroll tax; 2) increasing the government's fiscal subsidiary to the pension program from 1/3 to $1 / 2$ of the total cost of the social security system, and 3) introducing a "macroeconomic slide" that would automatically adjust benefits for increases in life expectancy and decreases in the amount of people who are insured in the program (Saito, 2017).

The reform was successful in raising the contribution rate from $13.58 \%$ in 2004 to $18.3 \%$ in 2017 (Kitao, 2017). This increased contribution rate is to help offset the decline in people paying into the system and continued growth in the length of time and the amount of people receiving benefits. However, the contribution rate is not set to rise further and wages are expected to decrease because of the decline of members in the labor force, meaning that contributions will still continue to decrease (Kitao, 2017).

The macroeconomic slide proposed to decrease the replacement rate, the amount of preretirement earnings replaced by one's pension, from 59.3\% in 2004 to 50.2\% in 2023 (Sakamoto, 
2005). While this would allow pension payments to become more feasible, this element of the 2004 reform was postponed, as some projections anticipated that it may bring the replacement down by $20 \%$, which would make for a replacement rate that is less than $50 \%$ of pre-retirement earnings. This, it was argued, is too low as it does not give retirees a lot to retire on (Saito, 2017). Despite this a plan for reform put forth by Sagiri Kitao contends that it is imperative that the replacement rate is decreased by $20 \%$ from the 2004 levels, bringing it to roughly $47.5 \%$, as Japan's Social Security System is still unsustainable (Kitao, 2017).

Kitao's plan has two elements of reform: 1) a decrease in the replacement rate by $20 \%$, and 2) an increase in the full benefit age from 65 to 68 , both of which would take place over a 30-year period (Kitao 2017). The 30-year period over which it will be adjusted will not cause any large change in consumption or income between any generation. The question that Kitao is left with is when would be best to begin this policy. While this it could be enacted up to 30 years in the future, it would be most effective in preserving the wellbeing of the economy if it is enacted as soon as 2020 . However, this policy will affect already retired members of society by decreasing their pensions. The decision of "when" is an issue to be discussed for future research, as it is a question of whether the cost of reducing benefits to the retired is unfair, as it could cause undue stress, even with the gains of helping the general public.

One drawback to this plan being enacted, and especially to it being enacted in 2020, is the issue of raising the age at which normal benefits can be claimed. As was noted in the section previous, increasing the age at which normal benefits can be received, while it will initially increase the labor force, may cause undue stress, as people decide to retire for reasons other than their Social Security pensions. While this concern is legitimate, it is important to remember that 
the age at which early benefits can be claimed, 60, will not be changed, still giving participants the chance to retire early.

Another issue is that the policy will be followed by an initial drop in labor supply, as the marginal benefits to working more hours will be reduced (Kitao, 2017) However, estimations show that this will be outweighed by the positive effects such as an eventual $4 \%$ rise in the labor force coupled with a $10 \%$ increase in capital by 2050 , if the plan is enacted as soon as 2020 . The effect of this will be a 0.5 to $1.2 \%$ increase in earning as opposed to the option of waiting till 2030 or 2040 to enact this policy (Kitao, 2017).

\section{Conclusion}

The Social Security system in both Japan and America were not set up in a way that can sustainably continue under current demographical changes, and it is imperative that they undergo reform. The issues of prolonged life expectancy, and trends toward early retirement in the US, have left both systems in a state that is actuarially unsound. While the Social Security system in Japan faces an arguably more urgent situation, they also seem to be more prepared to deal with it, due to their 2004 reform that increased contribution rates.

The US could undergo a number of reforms, but the most sustainable reform would be one that changes alongside its demographics. Deficits caused by increases in life expectancy and early retirement could be accounted for every year. Half of the following deficit would be covered by an increase in the payroll tax, while the other half could be covered by a decrease in benefits. This would be in effect along with the current increase in normal retirement age. This amendment to Social Security would allow for continued change in demographics, while also making Social Security once again actuarially sound. 
While Japan reformed their pension plan in 2004, further reform seems to be needed. Of the afore mentioned policy reform, only two aspects of it went into effect immediately. Namely the increase in pension contributions to $18.3 \%$ in 2017 and the increase of fiscal subsidiary by the government from $1 / 3$ to $1 / 2$ of the entire Social Security system. However, the macroeconomic scale was postponed in its inception, as it was projected that it could potentially reduce the replacement rate to below 50\%. Even so, it would be in the nations interest to decrease the replacement rate by $20 \%$ from the 2004 replacement rate, while at the same time increasing the normal retirement age to 68 . This would allow for the system to be sustainable well into the foreseeable future.

While no plan from either the Japanese or US Social Security system should be copied exactly, there are aspects of both that could be useful to each perspective country, if they were modified to fit demographic changes. The US should, like Japan, increase the contribution rate in the form of an increased payroll tax. Furthermore, it would also be in their interest to decrease replacement rates through benefit reductions. Japan could also look to the US's 1983 reform that began increasing the age at which normal benefits could be accessed. Currently, there are plans in both countries that do work to change these aspects of social security, as noted in section 4 , but figuring out when and how exactly to do this can be difficult and needs to continue being investigated until a plan that can both increase longevity within the system, as well as successfully be implemented, is found. 


\section{REFERENCES}

Barr, N., \& Diamond, Peter A. (2010). Pension reform : A short guide. New York: Oxford University Press.

Benefit Calculation Examples For Workers Retiring In 2018. (n.d.). Retrieved from https://www.ssa.gov/oact/progdata/retirebenefit2.html

Bitinas , A. (2012). Pension System in Japan: Issues for Reform . Jurisprudence . Retrieved February 01, 2018, from https://www.mruni.eu/upload/iblock/794/15_Bitinas.pdf.

Bureau, U. C. (2017, June 22). The Nation's Older Population Is Still Growing, Census Bureau Reports. Retrieved March 06, 2018, from http://www.census.gov/newsroom/pressreleases/2017/cb17-100.html

Diamond, P. A., \& Orszag, P. R. (2004). Saving Social Security: A Balanced Approach. Washington, D.C.: Brookings Institution Press.

Diamond, P. A., \& Orszag, P. R. (2005). Saving Social Security: The Diamond-Orszag Plan. The Economists Voice,2(1). doi:10.2202/1553-3832.1080

Gruber, J., \& Diamond, P. (n.d.). Social Security and Retirement in the United States. Chicago: University of Chicago Press .

Gruber, J., \& Wise, D. (1998). Social Security and Retirement: An International Comparison. The American Economic Review,158-163.

Saito, J. (2017, October 23). "Macroeconomic Slide” Mechanism of the Japanese Pension System. Retrieved April 25, 2018, from https://www.jcer.or.jp/eng/research/pdf/saito20171023e.pdf

Kitao, S. (2017). When do we Start? Pension reform in ageing Japan. The Japanese Economic Review,68(1), 26-47. doi:10.1111/jere.12135

Kromer, B., \& Howard, D. (2013, January 01). Library. Retrieved from https://www.census.gov/library/publications/2013/acs/acsbr11-09.html

Labor situation in Japan and its analysis general overview 2013/2014. (2014). Tokyo: The Japan Institute for labour policy and training.

Life expectancy at birth, total (years). (n.d.). Retrieved from https://data.worldbank.org/indicator/SP.DYN.LE00.IN?locations=US

Marlow, I. (2015, November 13). Bold steps: Japan's remedy for a rapidly aging society. Retrieved from https://www.theglobeandmail.com/globe-investor/retirement/retireplanning/how-japan-is-coping-with-a-rapidly-aging-population/article27259703/ 
Murakami, K. (1985). Retirement benefits and pension plans in Japan (Institute of Comparative Culture business series bulletin ; no. 102). Tokyo: Sophia University.

Noguchi, Y., Wise, David A, National Bureau of Economic Research, \& Nihon Keizai Kenkyū Sentā. (1994). Aging in the United States and Japan economic trends (NBER-Conference Report). Chicago: University of Chicago Press.

Quinn, J. B. (2013, October 01). Working Retirees: Know When to Caim Social Security Benefits. Retrieved April 14, 2018, from https://www.aarp.org/work/social-security/info10-2013/when-to-claim-social-security-benefits.html

Sakamoto, J. (2005). Japan's Pension Reform(p. 6, Rep. No. 0541). World Bank.

Service, J. P. (n.d.). National Pension System. Retrieved April 14, 2018, from http://www.nenkin.go.jp/international/english/nationalpension/nationalpension.html

Social Security in Japan. (n.d.). Retrieved April 14, 2018, from http://www.mofa.go.jp/j_info/japan/socsec/maruo/maruo_5.html

SSA Revises Payroll Tax Cap for 2018; Tax Law Alters Rates and Brackets. (2018, April 12). Retrieved April 14, 2018, from https://www.shrm.org/resourcesandtools/hrtopics/compensation/pages/fica-social-security-tax-2018.aspx

Social Security a Brief History. (2018, May 6). Retrieved from https://www.ssa.gov/history/pdf/2005pamphlet.pdf

US Census Bureau. (2017, June 22). The Nation's Older Population Is Still Growing, Census Bureau Reports. Retrieved from https://www.census.gov/newsroom/pressreleases/2017/cb17-100.html

Yashiro, N., \& Oshio, T. (1999). Social security and retirement in Japan. Chicago: University of Chicago Press. 